\title{
The efficacy of commercial silicones against blue stain and mould fungi in wood
}

\author{
Shyamal C. Ghosh $\cdot$ Holger Militz $\cdot$ Carsten Mai
}

Published online: 30 January 2009

(c) The Author(s) 2009. This article is published with open access at Springerlink.com

\begin{abstract}
Scots pine (Pinus sylvestris L.) samples were vacuum pressure impregnated with quaternary ammonium (quat)-silicone micro-emulsion ( $<40 \mathrm{~nm}$ particle size), amino-silicone macro-emulsion $(110 \mathrm{~nm})$ and silicone macro-emulsion with alkyl modified side groups $(740 \mathrm{~nm})$. Quat-silicone micro-emulsion caused highest cell wall bulking $(4.8 \%)$ and anti-swelling efficiency $(21.8 \%)$ in wood when treated with $30 \%$ concentration of silicone in the treatment solution. All three formulations made wood hydrophobic which was evident from a capillary (longitudinal, tangential and radial) water uptake test. Amino-silicone macro-emulsion (10\% silicone in treatment solution) resulted in strong resistance to blue stain attack with both pre-weathered and not pre-weathered wood samples. Signs of blue staining were more evident on the pre-weathered samples. Treatment with amino-silicone macro-emulsion ( $10 \%$ silicone in treatment solution) resulted in a certain resistance to mould growth on wood surfaces, whereas wood treated with the same concentration of quat-silicone microemulsion and alkyl-modified silicone macro-emulsion exhibited comparatively lower resistance.
\end{abstract}

\section{Die Wirksamkeit kommerzieller Silicone gegenüber Bläue- und Schimmelbefall auf Holz}

Zusammenfassung Kiefernholzproben (Pinus sylvestris L.) wurden unter Vakuum-Druck mit Emulsionen von drei Silicontypen imprägniert: der Mikro-Emulsion eines Sili-

S. C. Ghosh · H. Militz · C. Mai (

Wood Biology and Wood Products, Burckhardt Institute,

Georg-August University,

Büsgenweg 4,

37077 Göttingen, Germany

e-mail: cmai@gwdg.de cons mit quaternären Ammoniumgruppen (Quat-Silicon, $<40 \mathrm{~nm}$ Partikelgröße), der Makro-Emulsion eines AminoSilicons $(110 \mathrm{~nm})$ und der Makro-Emulsion eines Silicons mit alkyl-modifizierten Seitengruppen $(740 \mathrm{~nm})$. Die Mikro-Emulsion des Quat-Silicons verursachte die höchste Zellwandausdehnung (,Bulking“, 4,8\%) und Quellvergütung (,ASE“, 21,8\%) bei Holzproben, die mit 30\%iger Siliconlösung behandelt wurden. Eine Untersuchung der kapillaren Wasseraufnahme (longitudinal, tangential und radial) machte deutlich, dass alle drei Formulierungen das Holz hydrophobieren.

Die Makro-Emulsion des Amino-Silicons (10\% SiliconKonzentration in der Behandlungslösung) bewirkte sowohl bei vorbewitterten als auch bei nicht vorbewitterten Proben eine hohe Resistenz gegenüber Bläuebefall. Hierbei war der Bläuebefall auf den vorbewitterten Proben deutlicher zu erkennen. Die Behandlung mit der Makro-Emulsion des Amino-Silicons (10\% Silicon-Konzentration in der Behandlungslösung) ergab eine gewisse Resistenz gegenüber Schimmelbefall auf Holzoberflächen, während Hölzer, die mit der Mikro-Emulsion des Quat-Silicons und der MakroEmulsion des alkyl-modifizierten Silicons behandelt wurden, eine vergleichsweise geringe Resistenz aufwiesen.

\section{Introduction}

Recent wood protection research has focused on treating wood with highly specific organic chemicals of low mammalian and environmental toxicity, which are free of heavy metals in their formulations and are resistant to leaching (Evans 2003). In addition to biocidal treatment, water repellents have been applied in order to lower the moisture content of wood in service and, thus, to prevent its colonization by decay fungi. Various types of nonpolar agents 
such as oil, wax (Borgin and Corbett 1970), silanes (Mai and Militz 2004a,b, Donath et al. 2004, 2006a, Hill et al. 2004) or silicones (Sèbe and Brook 2001, Weigenand et al. 2007) have been applied to achieve water repellence.

Biocompatibility, optical and mechanical properties along with widespread industrial applications of polydimethylsiloxanes (PDMS) or silicones as hydrophobic agent has rendered them to get recurring attention in recent years (Vaidya and Kumar 1999a), even though the market of silicones is over 60-year-old (Owen 2008). Hager (1995) mentioned that the characteristic behavior of silicones to impart water repellency without reducing water vapor permeability is worth applying them as protective agents of mineral substrates. Silicones for masonry protection and plasters act as sealants, additives or primers, while those added to construction chemicals operate as water repellents, oil repellents, damp-roofing agents or stone strengtheners (Mayer 1998). Quaternary amine derivatives of siloxanes have been reported to have surface active properties and excellent binding to primarily negatively charged substrates like hair and fabrics (Vaidya and Kumar 1999b). They are also applied as emulsifiers (Ziemelis and Roth 1984), hair and skin conditioning agents for human (Ziemelis and Roth 1984), textile softeners (Martisons and Provatas 1994) etc. Nevertheless, aminosiloxanes are considered as a relatively new class of polymers, which are rapidly developing in the field of chemistry and personal care applications (Martisons and Provatas 1994). Recently it was shown that treatment with micro- and macro-emulsions of an amino-silicone reduced water uptake of Scots pine sapwood in a submersion test. Penetration of greater amounts of silicone into the wood cell wall, however, was only achieved with the micro-emulsion. This resulted in an increase in the volume of the wood specimens, which can be attributed to cell wall bulking. Moderate dimensional stability (up to 34\% anti-shrink-efficiency, ASE) was observed as a consequence (Weigenand et al. 2007). Papadopoulos and Hill (2002) considered cell wall bulking and micro-pore blocking as a major reason for high resistance of esterified wood against basidiomycetes, since extra-cellular enzymes or other decay agents excreted by fungi are not able to penetrate into the cell wall.

Several studies have focused on the effect of silicon based agents on wood decay by basidiomycete fungi (Tanno et al. 1998, Hill et al. 2004, De Vetter and Van Acker 2005, Do- nath et al. 2006b, Weigenand et al. 2008). It turned out that polysiloxanes bearing amino-functional groups exhibited high activity against decay fungi (Donath et al. 2006b, Weigenand et al. 2008), but little is known on the resistance of wood treated with amino-silicon products against staining fungi (Hill 2006). The amino-group in the siloxanes was considered to exert a mode of action comparable to tertiary amines and quaternary ammonium compounds (QACs, Donath et al. 2006b, Weigenand et al. 2008).

Tertiary amine and QACs have already been extensively studied and are used as conventional wood preservatives (Eaton and Hale 1993, Preston 1983, Pernak et al. 1998). Nevertheless it is argued that wood preservatives such as QACs giving good protection against basidiomycetes (Ruddick 1986, Doyle and Ruddick 1993, Dubois and Ruddick 1997, 1998) often fail against blue-stain and mould fungi (Willeitner 1976). Blue stain and mould fungi usually start growing superficially on wood surfaces; blue stain fungi may later penetrate into the wood. Both fungal groups are of significant economic importance because of loss of aesthetic qualities of wood in service (Eaton and Hale 1993, Hill 2006).

It is assumed that amino-siloxanes cause protection against fungi due to hydrophobation and due to the interaction of amino-silicone with the wood surface that prevents colonisation. This work is aimed at investigating the efficacy of three commercial silicone emulsions with aminofunctional, quaternary amino-functional and alkyl (without nitrogen) modified side groups to increase dimensional stability, water repellence and resistance against the growth of blue stain and mould fungi of Scots pine sapwood.

\section{Materials and methods}

\subsection{Chemicals}

Three commercial silicone emulsions (Momentive $\mathrm{GmbH}$, Leverkusen, Germany) were tested to impregnate Scots pine (Pinus sylvestris L.) sapwood (Table 1). In order to adjust the treatment concentration (wt/wt), the silicone emulsions were diluted with demineralised water considering the silicone content. Samples treated with only demineralised water served as a control.
Table 1 Name and chemical properties of silicone emulsions tested

Tabelle 1 Name und Eigenschaften der untersuchten Silicon-Emulsionen

\begin{tabular}{lccccc}
\hline Formulation & $\begin{array}{c}\text { Emulsion } \\
\text { particle } \\
(\mathrm{nm})\end{array}$ & $\begin{array}{c}\text { Silicone } \\
\text { content } \\
(\%)\end{array}$ & $\begin{array}{c}\text { Solid } \\
\text { content } \\
(\%)\end{array}$ & $\begin{array}{c}\mathrm{N} \text {-content } \\
\left(\mathrm{mmol} \mathrm{g}^{-1}\right)\end{array}$ & $\begin{array}{c}\text { Structure of } \\
\text { functional } \\
\text { group }\end{array}$ \\
\hline $\begin{array}{l}\text { Quat silicone micro-emulsion } \\
\text { QuatSiMiE) }\end{array}$ & $<40$ & 35 & 47 & 0.25 & $\begin{array}{c}\text { quaternary ammonium, } \\
\mathrm{R}^{1}-\mathrm{N}^{+}\left(\mathrm{CH}_{3}\right)_{2}-\mathrm{R}^{2}\end{array}$ \\
$\begin{array}{l}\text { Amino silicone macro-emulsion } \\
\text { (AminoSiMaE) }\end{array}$ & 110 & 35 & 38 & 0.25 & $\begin{array}{c}\mathrm{Amino}, \\
\left(\mathrm{CH}_{2}\right)_{3}-\mathrm{NH}_{2}\end{array}$ \\
$\begin{array}{l}\text { Alkyl modified silicone } \\
\text { macro-emulsion (AlkylSiMaE) }\end{array}$ & 740 & 35 & 38.5 & 0 & $\begin{array}{c}\text { Alkyl modified, } \\
\left(-\mathrm{CH}_{12}-\mathrm{C}_{14}\right)\end{array}$ \\
\hline
\end{tabular}


2.2 Weight percent gain (WPG), bulking and anti swelling efficiency (ASE)

Scots pine (Pinus sylvestris L.) sapwood $\left(25 \times 25 \times 10 \mathrm{~mm}^{3}\right.$, $\mathrm{R} \times \mathrm{T} \times \mathrm{L}$ ) was treated with water based solutions of silicone emulsions (5, 15 and $30 \%$ silicone concentration, $\mathrm{wt} / \mathrm{wt}$ ) using 100 mbar vacuum $(1 \mathrm{~h})$ followed by 12 bar pressure $(1 \mathrm{~h})$. The impregnated wood samples were subsequently dried gradually for one day at $30,60,80$ and $103^{\circ} \mathrm{C}$ (4 days total drying time), respectively. Weight percent gain (WPG) of treated samples was related to the oven dry weight of respective sample. Six replicas $(n=6)$ were used in this test.

Volume of oven dried samples before and after treatment was compared to calculate the cell wall bulking resulting from impregnation of silicone (Donath et al. 2004). The weight percent gain that caused bulking (WPB) was calculated according to Weigenand et al. (2007).

WPB [\%] $=\frac{\left(V_{\text {treated }}-V_{\text {untreated }}\right) \times d_{\text {silicone }}}{m_{\text {untreated }}} \times 100$

$V$ : volumes of the specimens before and after treatment $\left[\mathrm{cm}^{3}\right] ; m_{\text {untreated }}$ : dry mass of the wood specimens before treatment [g]; $d_{\text {silicone }}$ : density of silicone $\left(0.97 \mathrm{~g} \mathrm{~cm}^{-3}\right)$.

The anti-swelling efficiency (ASE) of treated wood blocks was calculated between the oven dried and water saturated state and was expressed as the ratio of the volumetric swelling coefficients of treated and untreated samples (Donath et al. 2004).

\subsection{Capillary water uptake}

Capillary water uptake along three directions (longitudinal, tangential and radial) was tested according to DIN 52617 (1987). Wood samples for longitudinal uptake $(20 \times 20 \times$ $\left.200 \mathrm{~mm}^{3}, \mathrm{R} \times \mathrm{T} \times \mathrm{L}\right)$ and for tangential and radial uptake $\left(40 \times 40 \times 40 \mathrm{~mm}^{3}, \mathrm{R} \times \mathrm{T} \times \mathrm{L}\right)$ were treated with silicone emulsions (15\% silicone). Five replicas were used; water impregnated samples served as a control. The samples were sealed along four faces keeping only the cross sections, the radial or the tangential faces open to test longitudinal, tangential and radial water uptake. The samples were set on a water saturated sponge so that the wood samples took up water only through the face in contact with the sponge. Water uptake was calculated as $\mathrm{kg} \mathrm{m}^{-2}$ after 1, 2, 3, $4,5,6,9,12,24,48 \mathrm{~h}$. The test was terminated when water reached the face opposite to that in contact with the saturated sponge. The water uptake coefficient was calculated for all three directions considering the uptake data of the first $24 \mathrm{~h}$ using the equation, $w_{t}=\Delta W_{t} \Delta t^{-0.5}$, where $w_{t}$ is the water uptake coefficient $\left(\mathrm{kg} \mathrm{m}^{-2} \mathrm{~h}^{-0.5}\right), \Delta W_{t}$ is the mass of water uptake per area $\left(\mathrm{kg} \mathrm{m}^{-2}\right)$; and $t$ is the time (h).

\subsection{Blue stain test}

The efficacy of silicone emulsions to protect wood against blue stain was tested according to EN 152 (1988) using $\mathrm{Au}$ reobasidium pullulans and Sclerophoma pithyophila combined in a spore suspension. Scots pine sapwood specimens $\left(40 \times 10 \times 75 \mathrm{~mm}^{3}, \mathrm{R} \times \mathrm{T} \times \mathrm{L}\right)$ were treated with the aqueous emulsions ( $4 \%$ and $10 \%$ silicone content, wt/wt) as described above. Water treated specimens served as controls. Six replicas were used per treatment. From every treatment a set of 6 samples was exposed to a weathering schedule of two sub-cycles (Table 2) in a UV cabinet with spray option (QUV, Q-Panel, Lab Products, Cleveland, USA). The exposure time was two weeks (one week in each sub-cycle).

Fourier-transform infrared (FT-IR) spectra of pre-weathered sample surfaces were taken using a Vector 22 spectrometer (Bruker, Bremen, Germany) with an ATR unit (DuraSamplIR II, SensIR Technologies, Danbury, USA) operating on 32 scans and at $4 \mathrm{~cm}^{-1}$ resolution. Both the pre-weathered and unweathered samples were kept at $20^{\circ} \mathrm{C}$ and $65 \%$ RH for one week. Afterwards sterilized ( $\gamma$-irradiation, $25 \mathrm{kGy}$ ) specimens were dipped ( $15 \mathrm{~s})$ in the mixed spore suspension of the test fungi and placed horizontally over vermiculite medium, which was also inoculated with $15 \mathrm{ml}$ spore suspension. Preweathered faces were always placed upward from vermiculite (no direct contact). After 6 weeks of incubation the samples were evaluated and ranked (rank 0: no staining to rank 3: more than $75 \%$ staining) according to EN 152 (1988). Blue stained area was calculated using ENVI 4.0 (ITT Visual Information Solutions) image processor according to Nguyen et al. (2007) and ranked according to the standard. The stained samples were crosscut $10 \mathrm{~mm}$ from each end and in the middle to observe the penetration of fungal hyphae.
Table 2 Description of QUV weathering cycles and the duration of the steps

Tabelle 2 Beschreibung der QUV-Bewitterungszyklen und der Dauer der Schritte

\begin{tabular}{lclrrr}
\hline & Step & \multicolumn{1}{c}{ Function } & Temperature & Duration & Condition \\
\hline Sub-cycle A & 1 & UV (A) & $(60 \pm 3)^{\circ} \mathrm{C}$ & $23 \mathrm{~h}$ & Wave band \\
& 2 & Condensation $(100 \% \mathrm{RH})$ & $(45 \pm 3)^{\circ} \mathrm{C}$ & $1 \mathrm{~h}$ & $300-400 \mathrm{~nm}$, \\
& 3 & Spray & & $4 \mathrm{~h}$ & max. $0.77 \mathrm{~W} \mathrm{~m}^{-2} \mathrm{~nm}^{-1}$ \\
& 4 & Condensation $(100 \% \mathrm{RH})$ & $(45 \pm 3)^{\circ} \mathrm{C}$ & $2 \mathrm{~h}$ & at $340 \mathrm{~nm}$ \\
& 5 & Spray & $10 \mathrm{~h}$ & \\
& 6 & Condensation $(100 \% \mathrm{RH})$ & $(45 \pm 3)^{\circ} \mathrm{C}$ & $2 \mathrm{~h}$ & \\
Sub-cycle B & 7 & Spray & $(60 \pm 3)^{\circ} \mathrm{C}$ & $22 \mathrm{~h}$ & \\
& 1 & UV (A) & $(45 \pm 3)^{\circ} \mathrm{C}$ & $102 \mathrm{~min}$ & \\
& 2 & Condensation $(100 \% \mathrm{RH})$ & & $18 \mathrm{~min}$ & \\
\hline
\end{tabular}




\subsection{Mould test}

The ability of silicone emulsions to protect wood against mould fungi was tested according to BS 3900 (1989). Scots pine sapwood specimens $\left(10 \times 75 \times 100 \mathrm{~mm}^{3}, \mathrm{R} \times \mathrm{T} \times \mathrm{L}\right)$ were treated with aqueous silicone emulsions (4 and $10 \%$ silicone content, wt/wt), as described above. Water treated specimens served as controls. Six replicas were used per treatment. The specimens were inoculated with a mixture of fungal spores containing Aspergillus versicolor, Aureobasidium pullulans, Cladosporium cladosporioides, Penicillium purpurogenum, Phoma violacea, Rhodotorula rubra, Stachybotrys chartarum and Ulocladium strum. The inoculated specimens were incubated in a test vessel under unsterile conditions with constant temperature $(25 \pm 2)^{\circ} \mathrm{C}$. The growth of mould fungi was monitored weekly over 8 weeks and ranked according to the standard (rank 0: no mould growth to rank 5: more than $70 \%$ coverage).

\section{Results and discussion}

\subsection{Weight percent gain (WPG), bulking} and anti-swelling efficiency (ASE)

QuatSiMiE and AminoSiMaE caused similar values for WPG when pine wood was treated with 5, 15 and 30\% silicone concentration in the impregnation solution, whereas AlkylSiMaE resulted in little lower WPG at all treatment concentrations (Fig. 1).
The highest cell wall bulking (volume increase of the samples after treatment) was achieved with QuatSiMiE $(4.8 \pm 0.4 \%)$, whereas that after treatment with AminoSiMaE and AlkylSiMaE amounted to $3.7 \pm 0.3 \%$ and $1.9 \pm 0.4 \%$, respectively, at $30 \%$ silicone concentration (Fig. 1a). At the same treatment concentration, QuatSiMiE induced 21.8\% ASE whereas AminoSiMaE and AlkylSiMaE brought about 19.0 and 5.4\% ASE (Fig. 1b). This trend coincides with previous findings that micro-emulsion caused greater bulking and ASE than macro-emulsions (Weigenand et al. 2007). The weight percent gain that causes bulking (WPB) was also highest with QuatSiMiE $(9.4 \%)$ at $47 \%$ WPG. This means that only $20 \%$ of the total WPG contributed to bulking, when wood blocks were treated with 30\% QuatSiMiE (Table 3). The calculation assumes that the volume change (here called bulking) caused by a chemical modification is solely due to the volume occupied by the chemical and that no void regions (free volume) exist around the infused chemicals (Nakano 1994, Hill and Mallon 1998, Weigenand et al. 2007). If such a void volume exists, the amount of silicone deposited within the cell wall should be even lower than the value calculated. The particle size distribution of the emulsions is polydisperse and it is assumed that only particles with a lower diameter than the cell wall micro-pores, which are reported to range from 2-4 nm (Tarkow et al. 1966, Stone and Scallan 1968, Flournoy et al. 1993), are deposited in the cell wall. Particles that exceed this critical diameter are deposited on the lumen surface of the cell wall. WPB decreased with increasing treatment concentration i.e., WPG. The proportion of emulsion particles below the critical size in QuatSiMiE ranges
Fig. 1 Bulking effect (a) and ASE (b) of Scots pine sapwood treated with silicone emulsions Abb. 1 „Bulking“-Effekt (a) und ASE (b) von mit

Silicon-Emulsionen behandeltem Kiefernsplintholz

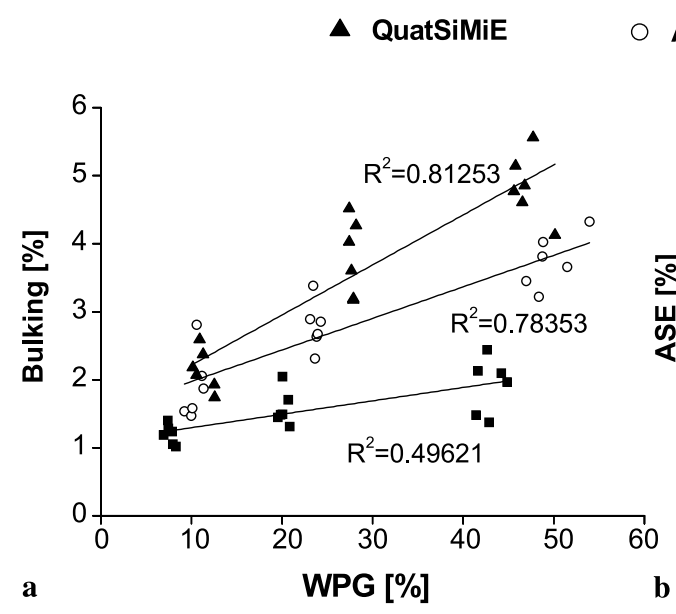

AminosiMaE

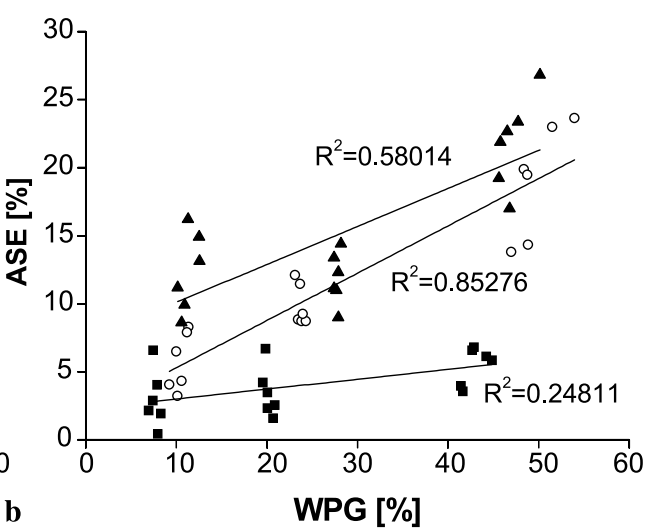

\begin{tabular}{ccccccc}
\hline Conc. & \multicolumn{2}{c}{ QuatSiMiE } & \multicolumn{2}{c}{ AminoSiMaE } & \multicolumn{2}{c}{ AlkylSiMaE } \\
& WPB & WPB/WPG & WPB & WPB/WPG & WPB & WPB/WPG \\
$(\%)$ & $(\%)$ & $(\%)$ & $(\%)$ & W $(\%)$ & $(\%)$ & $(\%)$ \\
\hline 5 & $4.2( \pm 0.5)$ & $37.6( \pm 6.1)$ & $3.7( \pm 1.0)$ & $35.4( \pm 9.1)$ & $2.3( \pm 0.2)$ & $30.7( \pm 4.1)$ \\
15 & $7.2( \pm 1.0)$ & $26.2( \pm 3.9)$ & $5.3( \pm 0.6)$ & $20.9( \pm 5.3)$ & $3.0( \pm 0.5)$ & $15.0( \pm 2.4)$ \\
30 & $9.4( \pm 0.8)$ & $20.0( \pm 2.0)$ & $7.4( \pm 1.0)$ & $15.0( \pm 1.4)$ & $3.7( \pm 0.8)$ & $8.7( \pm 1.8)$ \\
\hline
\end{tabular}

Table 3 WPG causing bulking (WPB) and the ratio of WPB to WPG

Tabelle 3 Das für das „Bulking“ verantwortliche WPG (WPB) und das Verhältnis von WPB zu WPG 
Fig. 2 Longitudinal (a), radial (b) and tangential (c) uptake (average of 5 samples) and the water uptake coefficient (d) of Scots pine wood treated with (15\% concentration) QuatSiMiE, AlkylSiMaE, AminoSMaE and control

Abb. 2 Longitudinale (a), radiale (b) und tangentiale (c) Wasseraufnahme (Durchschnitt von 5 Proben) und der Koeffizient der Wasseraufnahme (d) von QuatSiMiE, AlkylSiMaE, AminoSMaE behandeltem Kiefernholz (15\% Konzentration) und der Kontrolle
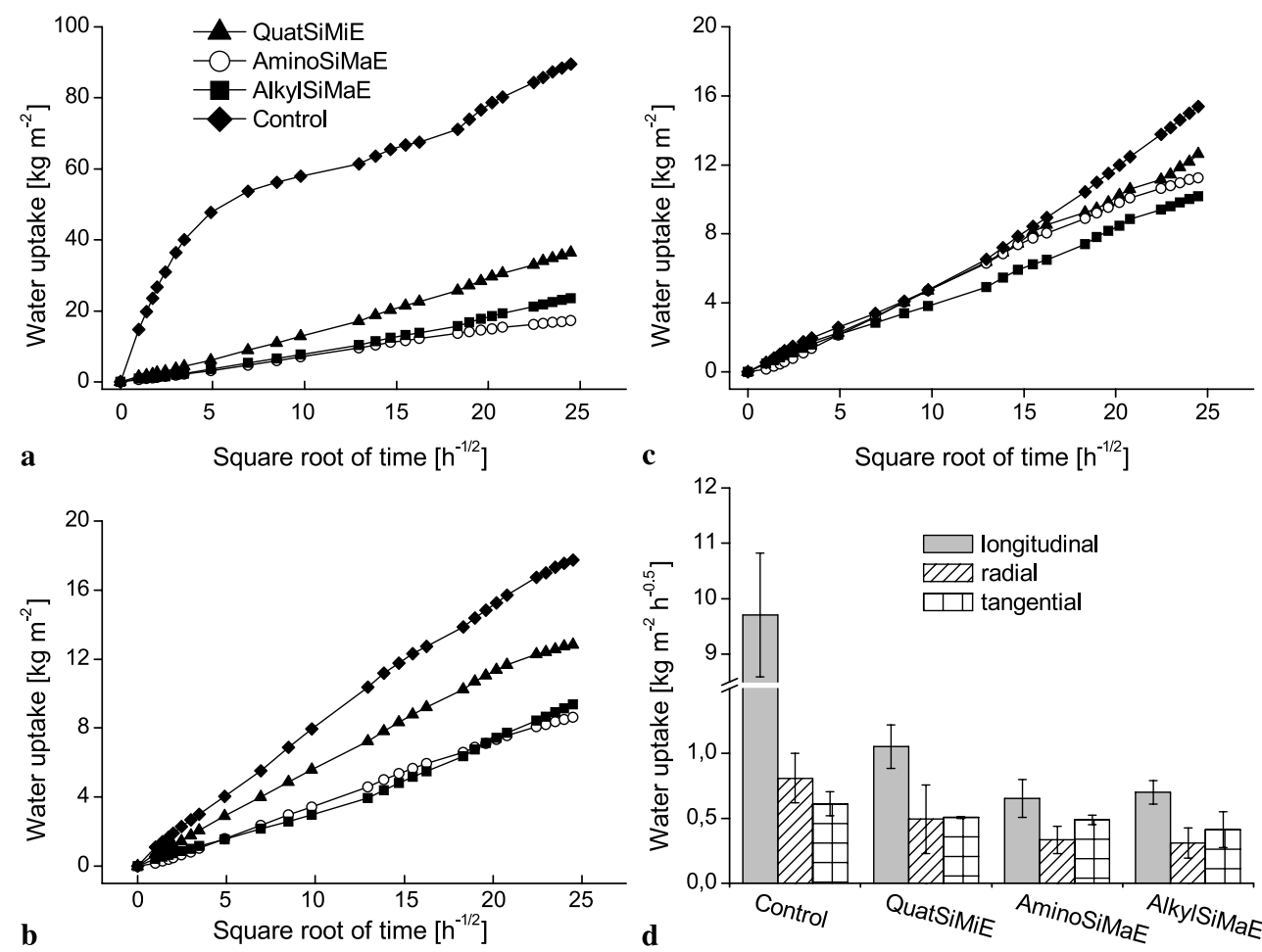

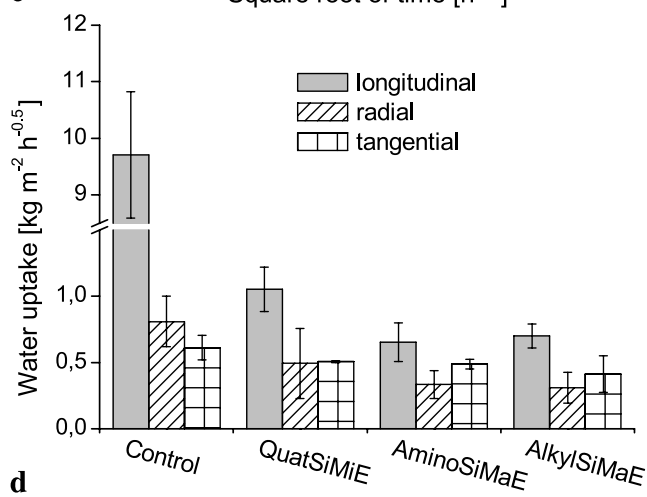

from 20 to 37.6\%, in AminoSiMaE from 15 to $35.4 \%$ and in AlkylSiMaE from 8.7 to $30.7 \%$.

\subsection{Capillary water uptake}

All treated and untreated specimens showed the highest water uptake in the longitudinal direction due to the longitudinal orientation of the tracheids; these make up approx. $90 \%$ of the cell elements in Scots pine (Panshin and de Zeeuw 1970). Tangential uptake was somewhat lower than the radial one as previously shown (Panshin and de Zeeuw 1970, Weigenand et al. 2007).

The water uptake was reduced in all three directions due to silicone treatment (Fig. 2a,b,c), but the most pronounced reduction was found for longitudinal uptake. The macroemulsions (AminoSiMaE, AlkylSiMaE) caused greater reduction in water uptake along all three directions than the micro-emulsion (QuatSiMiE, Fig. 2d). This might be due to deposition of greater amounts of silicone in the lumens of tracheids and rays as the main flow paths. SEM-EDX studies revealed that silicone of macro-emulsions partly filled tracheid lumens of both earlywood and latewood cells completely, while silicone of micro-emulsions covered only the inner lumen surface of tracheids (Weigenand et al. 2007).

\subsection{Blue stain}

Outdoor weathering results in greying of the wood surface. Greying is caused by a combination of photo-bleaching and colonisation of the bleached wood surface by staining fungi. The most prominent fungi on weathered wood surfaces are A. pullulans and S. pithyophila, which belong to the ecological group of blue stain fungi. In addition, Hormonema dematioides is another species of blue stain fungi also found to grow on wood surfaces (Ray et al. 2004). These ascomycetous fungi are not able to decay the wood cell wall but feed on photo-degraded cell wall products (Schoeman and Dickinson 1997). Silicone modified wood and water impregnated control samples were weathered in a QUV to produce these cell wall debris and to enhance surface colonisation by blue stain fungi. The FTIR spectra of all samples prior to weathering displayed the absorption band of lignin at $1505 \mathrm{~cm}^{-1}$ corresponding to aromatic skeletal vibrations (Fig. 3). Silicone treated samples showed absorption bands at $1257 \mathrm{~cm}^{-1}$ assigned to $v(\mathrm{Si}-\mathrm{C})$ stretch vibration, $1080 \mathrm{~cm}^{-1}$ and $1000 \mathrm{~cm}^{-1}$ assigned to skeletal vibrations $\delta(\mathrm{Si}-\mathrm{O}-\mathrm{Si})$ and $798 \mathrm{~cm}^{-1}$ assigned for $v(\mathrm{Si}-\mathrm{C})$ and/or $v$ (Si-O) (Noll 1968, Sèbe et al. 2004, Tinguat et al. 2005, Zollfrank and Wegener 2002, Zollfrank 2001). After weathering the lignin band at $1505 \mathrm{~cm}^{-1}$ disappeared due to UV degradation, whereas the intensity of the silicone bands did not diminish (Fig. 3).

Regardless of silicone type and treatment concentration, the pre-weathered surfaces were colonised to a greater extent than the un-weathered surfaces. Cell wall degradation products as easy available nutrients could have favoured the fungal growth on the pre-weathered surfaces (Schoeman and Dickinson 1997). In addition, fungal colonisation could 


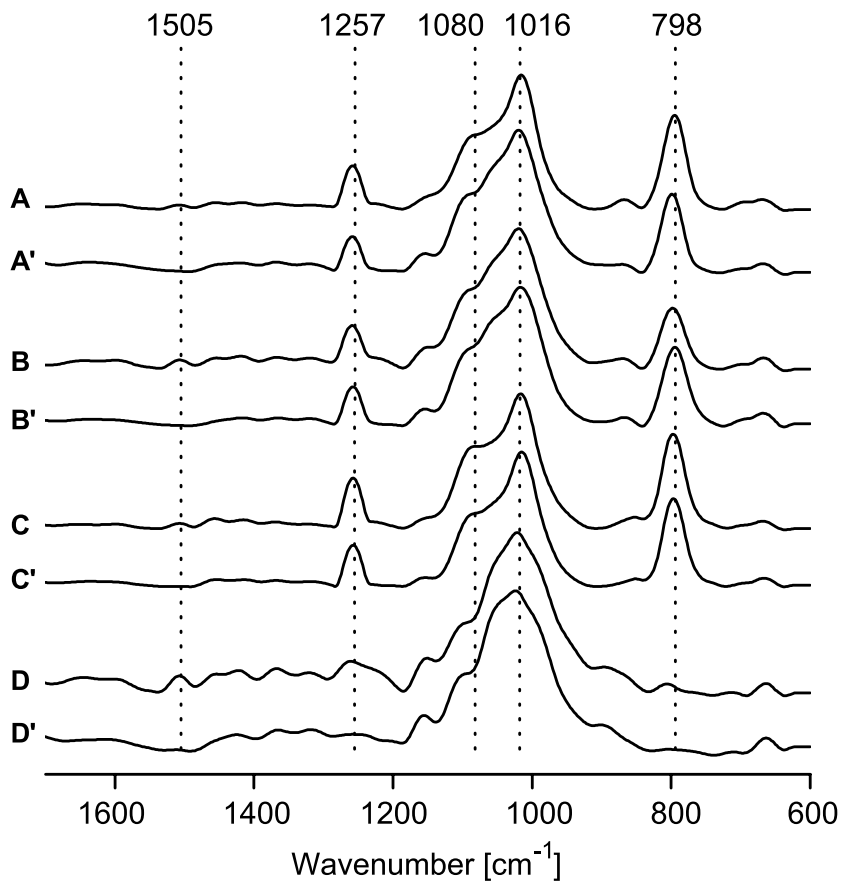

Fig.3 FTIR spectra of Scots pine treated with QuatSiMiE (A), AminoSMaE (B),AlkylSiMaE, (C) (10\% conc.) and water impregnated control before weathering and after weathering (A', B', C' and D')

Abb.3 FTIR-Spektren von mit QuatSiMiE (A), AminoSMaE (B), AlkylSiMaE (C) (alle 10\% Konz.) behandeltem Kiefernholz und der mit Wasser imprägnierten Kontrolle (D) vor und nach Bewitterung (A', B', C' und D')

have been enhanced through the removal of the hydrophobic lignin and the exposure of hydrophilic polysaccharides, especially cellulose.

In all cases of the not pre-weathered specimens, the surfaces in contact with vermiculite showed more stained area than the reverse surfaces; this might be due to the higher moisture content at the interface of wood and vermiculite.
Wood specimens treated with AminoSiMaE displayed the lowest degree of blue stain colonisation (Table 4). Although the treatment with both concentrations of AminoSi$\mathrm{MaE}$ resulted in the same ranking, the stained area was somewhat smaller on specimens treated with $10 \%$ silicone. AlkylSiMaE did not significantly increase resistance to blue staining, although the higher concentration $(10 \%)$ slightly reduced the staining area compared to $4 \%$. The same tendency was observed with QuatSiMiE. Not preweathered QuatSiMiE treated specimens, however, did not show any blue staining after treatment with $10 \%$ silicone concentration.

The staining of the cross-sections revealed a comparable trend in terms of infection as the tangential/radial surfaces for the different treatments. The control specimens displayed the highest extent of infection followed by specimens treated with AlkylSiMaE, QuatSiMiE and AminoSi$\mathrm{MaE}$ (Fig. 4). The fungi apparently started to grow from the surface in contact with vermiculite and penetrated through the ray cells. Staining of the reverse surface of control specimens appears to be caused by penetrating hyphae from the side in contact with vermiculite and by direct infection through spores. In specimens treated with AminoSiMaE, however, the hyphae started to grow through the ray cells, but could not entirely penetrate through the wood to reach the other surface. As for all treated specimens, this was more evident in specimens treated with the higher silicone concentration. The extent of fungal penetration through the cross-section was greater in case of pre-weathered specimens; this can be attributed to the stronger colonisation of the pre-weathered surfaces.

\subsection{Mould test}

The effect of silicone treatment on mould growth reduction followed the same trend as with blue stain infection.
Table 4 Percentage of blue stain and ranking of silicone emulsions treated wood surfaces (rank 0-3) Tabelle 4 Der prozentuale Anteil des Bläuebefalls und die Bewertung der mit Silicon-Emulsionen behandelten Holzoberflächen (Bewertung 0-3)

\begin{tabular}{lcccccc}
\hline Treatment & Conc. & $\begin{array}{c}\text { Exposed } \\
\text { to QUV }\end{array}$ & $\begin{array}{c}\text { Mean area of } \\
\text { stained surface } \\
\text { with vermiculite } \\
\text { contact }(\%)\end{array}$ & $\begin{array}{c}\text { Rank of } \\
\text { surface with } \\
\text { vermiculite } \\
\text { contact }\end{array}$ & $\begin{array}{c}\text { Mean area of } \\
\text { saining in the } \\
\text { reverse face of } \\
\text { vermiculite }(\%)\end{array}$ & $\begin{array}{c}\text { Rank of } \\
\text { reverse } \\
\text { surface }\end{array}$ \\
\hline QuatSiMiE & $4 \%$ & YES & $97.8 \pm 5.3$ & 3 & $95.6 \pm 3.0$ & 3 \\
& & NO & $93.5 \pm 0.8$ & 3 & $87.2 \pm 8.1$ & 3 \\
& $10 \%$ & YES & $82.7 \pm 6.1$ & 3 & $97.1 \pm 2.8$ & 3 \\
AminoSiMaE & $4 \%$ & NO & $84.7 \pm 7.0$ & 3 & 0 & 0 \\
& & YES & $10.9 \pm 9.0$ & 1 & $3.4 \pm 2.9$ & 1 \\
& \multirow{2}{*}{$10 \%$} & NO & $0.2 \pm 0.3$ & 1 & 0 & 0 \\
AlkylSiMaE & \multirow{2}{*}{$4 \%$} & NO & $1.2 \pm 2.0$ & 1 & $0.6 \pm 0.2$ & 1 \\
& & YES & $9.2 \pm 0.2$ & 1 & 0 & 0 \\
& \multirow{2}{*}{$10 \%$} & NO & $88.0 \pm 3.1$ & 3 & $90.8 \pm 5.4$ & 3 \\
YES & $81.5 \pm 14.1$ & 3 & $72.6 \pm 8.6$ & 2 \\
& & NO & $77.3 \pm 9.1$ & 3 & $76.2 \pm 5.7$ & 3 \\
& & YES & $96.0 \pm 4.2$ & 3 & $97.2 \pm 15.7$ & 2 \\
& & NO & $95.2 \pm 3.8$ & 3 & $98.6 \pm 0.4$ & 3 \\
\end{tabular}




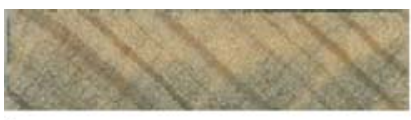

a

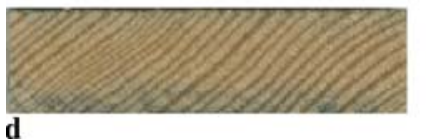

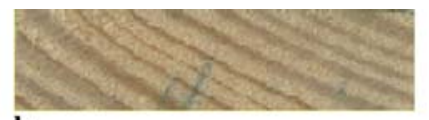

b

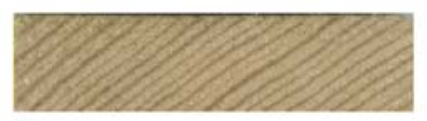

e

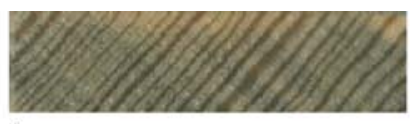

c

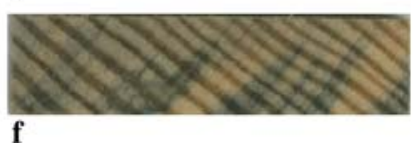

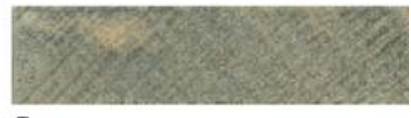

g

Fig. 4 Cross sectional view of blue stain penetration in not pre-weathered samples treated with $4 \%$ (a, b, c) and 10\% (d, e, f) concentration solution QuatSiMiE (a, d), AminoSMaE (b, e), AlkylSiMaE (c, f) and untreated control (g). The bottom side of the specimens was in contact with vermiculites

Abb. 4 Querschnittsansicht der Eindringung von Bläuepilzen in nicht-vorbewitterten Proben, die mit 4\% (a, b, c) und 10\% (d, e, f) Lösungskonzentration von QuatSiMiE (a, d), AminoSMaE (b, e), AlkylSiMaE (c, f) behandelt wurden und der unbehandelten Kontrolle (g). Die Unterseite der Proben war in Kontakt zum Vermikulit

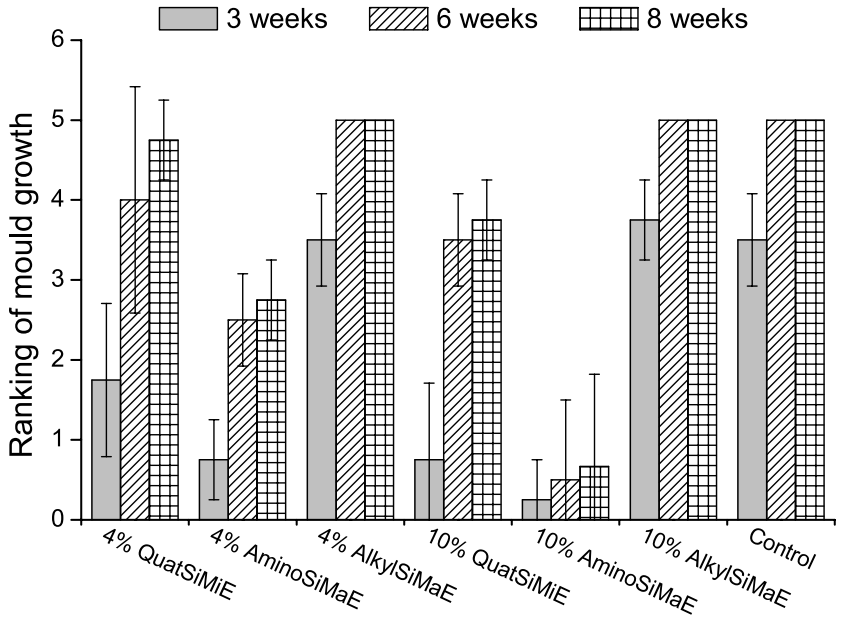

Treatment / concentration

Fig. 5 Mould growth (average rank of 5 replicas per treatment) on untreated and treated Scots pine wood (ranking 0-5)

Abb. 5 Schimmelbefall (Durchschnitt von 5 Wiederholungen pro Behandlung) auf unbehandeltem Splintholz (Bewertung 0-5)

AminoSiMaE reduced the mould growth to the greatest extent with increasing silicone concentration (Fig. 5). QuatSiMiE also reduced the growth, but AlkylSiMaE did not impart any resistance to mould growth.

The resistance against mould growth can be attributed to the primary amino (AminoSiMaE) and quat groups (Quat$\mathrm{SiMiE}$ ) in the silicones. AlkylSiMaE does not contain amino groups and consequently did not clearly reduce mould colonisation. Donath et al. (2006b) examined the effect of amino-functional silane oligomers against decay fungi and reported antifungal effect of the amino groups, whereas the alkyl groups played a minor role in decay resistance. Similarly, Weigenand et al. (2008) reported moderate antifungal effects of amino-silicone emulsions which were attributed to a negative impact of propyl-amino groups on fungal physiology.

AminoSiMaE and QuatSiMiE contain the same amount of nitrogen in their silicone molecules $\left(0.25 \mathrm{mmol} \mathrm{g}^{-1}\right)$.
This study indicates that silicones bearing primary amino groups affect the growth of blue stain and mould fungi more than quat-silicones. Quaternary ammonium compounds are widely used as wood preservative agents (Preston et al. 1987) and, thus, silicones bearing quat side-groups should display higher antifungal activity than those bearing primary amino groups. This indicates that the effect of the sidegroup on fungal physiology might not be the main reason for staining resistance. Growth of fungal hyphae on the surface of treated wood might also be impeded due to changes in the surface energy. It is possible that the amino-silicone changes the surface properties to a greater extent than the quat-silicone.

This effect, however, could also be influenced by the different type of emulsions used for the impregnation. QuatSiMiE was applied as a micro-emulsion (particle size lower than $40 \mathrm{~nm}$ ), AminoSiMaE as a macro-emulsion $(110 \mathrm{~nm})$. It is assumed that most of the silicone in AminoSiMaEtreated samples deposits on the surface of the wood specimens, since emulsion particles of macro-emulsions do not penetrate deeply into the wood matrix. The concentration of amino-silicone on the wood surface is therefore much higher than that of quat-silicone after treatment with QuatSiMiE. This higher concentration of amino-silicone on the specimens' surface compared to quat-silicone could be another reason for the higher activity against surface staining fungi. Further studies are necessary to compare the effects of amino- and quat-silicones on fungal growth separately from the effect of their penetration into the wood matrix.

Silicone emulsions hold the good potential to be used as commercial wood protection technique. Recent studies of Weigenand et al. (2007) as well as the results of the present study indicate that silicones can impart water repellence as well as partial dimensional stability in wood (dependent on particle size). Amino-silicone emulsions have been shown to improve the decay resistance in wood by basidiomycetes (Weigenand et al. 2008, Ghosh et al. 2008). This study reveals that wood treatment with amino-silicone also imparts resistance against surface disfiguration by mould and stain- 
ing fungi. The combination of different property enhancements makes the silicone emulsion a suitable biocide-free wood protective agent for the application in hazard class 3 according to EN 335 (2006).

\section{Conclusion}

A treatment of wood with silicone micro-emulsion $(\leq 40 \mathrm{~nm}$ particle size) improved the dimensional stability of wood more than with macro-emulsions $(110,740 \mathrm{~nm})$. This is due to the higher degree of penetration of smaller emulsion particles into the cell wall. Bigger emulsion particles are predominantly located in the cell lumens and have little effect on cell wall bulking and subsequent dimensional stabilization. Nevertheless, both micro- and macro-emulsions imparted hydrophobicity to wood. The studies reveal that the macro-emulsion with amino-silicones caused strong resistance against blue stain and moulds. This can either be explained by direct antifungal effects of the aminofunctional group or by changes in the surface properties of treated wood. Water repellence appears to have a minor contribution to the resistance against staining fungi, since the amino-free AlkylSiMaE did not reduce fungal colonisation but imparted a comparable degree of hydrophobicity to the wood specimens as the most effective AminoSiMaE.

Acknowledgement The authors would like to acknowledge the contribution of Momentive $\mathrm{GmbH}$, Leverkusen, Germany for supplying the chemicals and technical information.

Open Access This article is distributed under the terms of the Creative Commons Attribution Noncommercial License which permits any noncommercial use, distribution, and reproduction in any medium, provided the original author(s) and source are credited.

\section{References}

Borgin K, Corbett K (1970) Stability and weathering properties of wood treated with various oils, waxes and resins. Plast Paint Rubber 4:69-72

BS 3900 (1989) Methods of test for paints - Assessment of resistance to fungal growth, Part G6. British Standards

De Vetter L, Van Acker J (2005) Standard testing of organosilicon compounds as wood modification agents. In: Militz H, Hill C (eds) Wood Modification: Processes, Properties and Commercialisation. The second European conference on wood modification. 6th-7th October 2005, Göttingen, Germany, pp 232-241

DIN 52617 (1987) Bestimmung des Wasseraufnahmekoeffizienten von Baustoffen. Berlin, Germany

Donath S, Militz H, Mai C (2006a) Creating water repellent effects on wood by treatment with silanes. Holzforschung 60(1):40-46

Donath S, Miltz H, Mai C (2006b) Treatment of wood with aminofunctional silane for protection against wood destroying fungi. Holzforschung 60(2):210-216
Donath S, Miltz H, Mai C (2004) Wood modification with alkoxysilanes. Wood Sci Technol 38(7):555-566

Doyle AK, Ruddick JNR (1993) Isolation and identification of non-decay fungi affecting the performance of alkylammonium compounds. Document No. IRG/WP 93-10020. International Research Group on Wood Preservation, Stockholm, Sweden

Dubois JW, Ruddick JNR (1997) Aspects of fungal degradation of quaternary ammonium compounds in liquid culture. Document No. IRG/WP 97-30160. International Research Group on Wood Preservation, Stockholm, Sweden

Dubois JW, Ruddick JNR (1998) The fungal degradation of quaternary ammonium compounds in wood. Document No. IRG/WP 98-10263. International Research Group on Wood Preservation, Stockholm, Sweden

Eaton RA, Hale MDC (1993) Wood - Decay, Pests and Protection. Chapman and Hall, London, UK

European standard (1988) EN 152: Test methods for wood preservative - laboratory method for determining the preventive effectiveness treatment against blue stain in service - Part 1: Brushing procedure - Part 2: other methods. European Committee for Standardisation (CEN), Brussels, Belgium

European standard (2006) EN 335-1: Durability of wood and woodbased products - Definition of use classes - Part 1: General. European Committee for Standardisation (CEN), Brussels, Belgium

Evans P (2003) Emerging technologies in wood protection. For Prod J 53(1):14-22

Flournoy DS, Paul JA, Kirk TK, Highley TL (1993) Changes in the size and volume of pores in sweetgum wood during simultaneous rot by Phanerochaete chrysosporium Burds. Holzforschung 47(4):397-301

Ghosh SC, Militz H, Mai C (2008) Decay resistance of treated wood with functionalised commercial silicones. BioResources 3(4):1303-1314

Hager RD (1995) Waterborne silicones as wood preservatives. IRG/WP 95-30062. International Research Group on Wood Preservation, Stockholm, Sweden

Hill CAS (2006) Wood modification - chemical, thermal and other processes. John Wiley and Sons Ltd., West Sussex

Hill CAS, Mallon S (1998) The chemical modification of Scots pine with succinic anhydride or octenyl succinic anhydride I. Dimensional stabilisation. Holzforschung 52(4):427-433

Hill CAS, Mastery Farahani MR, Hale MDC (2004) The use of alkoxysilane coupling agents for wood preservation. Holzforschung 58(3):316-325

Mai C, Militz H (2004a) Modification of wood with silicon compounds. Treatment systems based on organic silicon compounds - a review. Wood Sci Technol 37(6):453-461

Mai C, Militz H (2004b) Modification of wood with silicon compounds. Inorganic silicon compounds and sol-gel systems: a review. Wood Sci Technol 37(5):339-348

Martisons JG, Provatas A (1994) Characterization of Novel Cationic Aminohydroxysiloxanes. Macromolecues 27:3397-3405

Mayer H (1998) Masonry protection with silanes, siloxanes and silicone resins. JOCCA - Surf Coat Int 81(2):89-93

Nakano T (1994) Mechanism of thermoplasticity of chemically modified wood. Holzforschung 48(4):318-324

Nguyen HM, Militz H, Mai C (2007) Protection of wood for above ground application through modification with a fatty acid modified N-methylol/paraffin formulation. Document No. IRG/WP 07-40378. International Research Group on Wood Preservation, Stockholm, Sweden

Noll W (1968) Chemie und Technologie der Silicone. 2nd edition. Verlag Chemie GmbH, Weinheim/Bergstraße, Germany

Owen MJ (2008) Say yes to silicones! [Si to Si]. In: Stephen JC, Fitzferald JJ, Owen MJ, Smith SD, Van Dyke ME (eds) Sci- 
ence and technology of silicones and silicone-modified materials. ACS Sym Ser 964:2-8

Panshin AJ, de Zeeuw C (1970) Textbook of wood technology, Vol. I. McGraw-Hill Book Company, New York, USA

Papadopoulos AN, Hill CAS (2002) The biological effectiveness of wood modified with linear chain carboxylic acid anhydrides against Coniophora puteana. Holz Roh- Werkst 60(5):329-332

Pernak J, Zabielska-Matejuk J, Urbanik E (1998) New quaternary ammonium chlorides - wood preservatives. Holzforschung 52(3):249-254

Preston AF (1983) Dialkyldimethylammonium halides as wood preservatives. J Am Oil Chem Soc 60:567-570

Preston AF, Walcheski PJ, McKaig PA, Nicholas DD (1987) Recent research on alkylammonium compounds in the U.S. Proc Am Wood Preserv Assoc 83:331-34

Ray MJ, Dickinson DJ, Buck M (2004) Aureobasidium or Hormonema? A Genetic Approach. IRG/WP 04-10529. International Research Group on Wood Preservation, Stockholm, Sweden

Ruddick JNR (1986) The influence of stain fungi on the decay resistance of wood treated with alkyldimethylbenzyl ammonium chloride. Mater Organismen 21:139-149

Schoeman MW, Dickinson DJ (1997) Growth of Aureobasidium pullulans (de Bary) Arnaud on lignin breakdown products at weathered wood surfaces. Mycologist 11:168-172

Sèbe G, Brook MA (2001) Hydrophobation of wood surfaces: covalent grafting of silicone polymers. Wood Sci Technol 35(3):269-282

Sèbe G, Tinguat P, Safou-Tchiana R, Pétraud M, Grelier S, De Jéso B (2004) Chemical reaction of maritime pine sapwood (Pinus pinaster Soland) with alkoxysilane molecules: A study of chemical pathways. Holzforschung 58(5):511-218

Stone JE, Scallan AM (1968) A structural model for the cell wall of water-swollen wood pulp fibres based on their accessibility to macromolecules. Cell Chem Technol 2:343-358
Tanno F, Saka S, Yamamoto A, Takabe K (1998) Antimicrobial TMSAH-added wood-inorganic composites prepared by the solgel process. Holzforschung 52(4):365-370

Tarkow H, Feist WC, Southerland CF (1966) Interaction of wood with polymeric materials. Penetration versus molecular size. For Prod J 16(10):61-65

Tinguat P, Weigenand O, Militz H, De Jèso B, Sèbe G (2005) Functionalisation of wood by reaction with 3-isocyanatopropylthiethoxysilane: Grafting and hydrolysis of the thriethoxysilane end groups. Holzforschung 59(4):397-404

Vaidya A, Kumar VG (1999a) Synthesis and studies on starch-gquaternary amino polysiloxane graft copolymers. J Macromol Sci 36(9):1323-1336

Vaidya A, Kumar VG (1999b) Synthesis and aggregation behavior of olefininc quaternary amino siloxanes. J Macromol Sci 36(4):587-603

Weigenand O, Humar M, Daniel G, Militz H, Mai C (2008) Decay resistance of wood treated with amino-silicone compounds. Holzforschung 62(1):112-118

Weigenand O, Militz H, Tingaut P, Sèbe G, de Jeso B, Mai C (2007) Penetration of amino-silicone micro- and macro-emulsions into Scots pine sapwood and the effect on water related properties. Holzforschung 61(1):51-59

Willeitner H (1976) Testing blue stain fungicides for joinery timber in combination with natural weathering. Document No. IRG/WP 76-268. International Research Group on Wood Preservation, Stockholm, Sweden

Ziemelis MJ, Roth CA (1984) Cationic polydiorganosiloxanes for treating proteinaceous substrates. US patent, 4472566

Zollfrank C (2001) Silylation of solid beech wood. Wood Sci Technol 35(2):183-189

Zollfrank C, Wegener G (2002) FTIR microscopy and ultrastructural investigation of silylated solid wood. Holzforschung 56(1):39-42 